\title{
A Regression Analysis of Generation Y Female Students' Perceptions on Social Risk, Buying Behaviour and Apparel Store Choice
}

\author{
Bakae Aubrey Mokoena*, Eugine Tafadzwa Maziriri \\ Vaal University of Technology, South Africa \\ aubrey@vut.ac.za*,210082534@edu.vut.ac.za
}

\begin{abstract}
In the present post-modern era, Generation Y female students are faced with a discerning process of selecting the optimum apparel retail store to be loyal to and from which to buy clothing products. Therefore, the active store choice decision is conceptualized as the difficulty of determining someplace and when and where to shop. The main objective of the study was to examine the relationship between social risk, buying behavior and store choice within the apparel retail industry. The study is positioned within a postpositivism quantitative paradigm and adopts a cross-sectional survey approach collecting data from 400 conveniently selected university students. Scale purification was done through pre-testing and pilot testing. Through multiple regression analysis, the results show that social risk and buying behavior significantly influences retail store choice in an apparel retail setting. The findings indicated that there is a positive and significant association between perceived social risk, buying behavior and retail store choice. Based on the outcomes of the study, recommendations were suggested to retail managers to develop retailing strategies that charm the female Generation Y consumers. In addition, limitations and future research directions are referred to.
\end{abstract}

Keywords: Apparel, perceived social risk; buying behavior; retail store choice; Generation Y female students

\section{Introduction}

A clear understanding of why customers choose a certain store over others has become a major objective of retail strategists and researchers (Muzondo \& Mutandwa, 2011). Zulqarnain, Zafar and Shahzad (2015) concur that the study of how consumers choose retail stores and what drives their store choice is an indispensable contribution to the retail sector. Du Plessis and Rousseau (2003) as well as Cooper (2010) supports Du Plessis and Rousseau (2003) assertion that consumers are challenged with decisions regarding the store choice as well as the products and services they buy daily. Therefore, since consumers are frequently uncertain about the consequences of their store and purchase decisions, they perceive a certain degree of risk when making a retail store choice. Social risk is associated with poor store choice decision that will result in social humiliation (Schiffman \& Kanuk, 2007; Peter \& Olson, 2005). In addition, Faarup (2010) describes social risk as the kind of risk that refers to how the reference group will observe the choice of retail store and the purchasing of a specific product. Therefore, a consumer can experience a low self-esteem if their social group, family and friends do not favorably perceive the reputation of the store (Amin \& Mahasan, 2014).

According to Diejomaoh (2013), consumer buying behavior can be understood as how, where and which retail store consumers prefer to buy products when confronted with buying decisions. It is of utmost importance for a retailer to understand the buying behavior of its consumers in order to develop retailing strategies that attract and keep clientele (Sinha, Banerjee, \& Uniyal, 2002). Prasad (2012) believes that while consumers often patronize many stores, they typically have a primary attachment to the "main store" that captures most of their purchases. Floor (2006) is of the view that store choice and buying behavior depends on the type of product, the time of purchase, the available budget and many other factors. According to Zulqarnain, Zafar and Shahzad (2015), consumers now consider a number of factors when choosing a retail store. Diverse store types or categories expose customers to a multiple of choices when choosing the store from where to make a purchase (Carpenter \& Brosdahl, 2011). The active store choice decision is conceptualized as the challenge of choosing when and where to shop (Leszczyc, Peter, Sinha \& Timmermans, 2000). Jayasankaraprasad (2010) reiterate that in the process of deciding which stores to frequent, consumers consider a number of risk factors, often alluded to as store choice evaluative criteria. Therefore, an understanding of how consumers evaluate quality and which variables influence their purchase decisions will assist retailers in choosing what commodities to stock (De Klerk \& Lubbe, 2008). 
Research Problem and Gap: One of the difficulties encountered by retailers includes developing an appreciation of the intervening variables relating to consumers store choices (Mowen, 1995). To this end, Karpova, Hodges and Tullar (2007) point out that a gap that emanates from ignorance regarding in respect of the wants and needs of customers also intensify challenges to retailers. Whilst many studies have focused on Generation Y consumers and students specifically (Bevan-Dye, Garnett \& De Klerk, 2012), there is scant research on buying behavior, social risk and their impact on retail store choice. Previous research has examined Generation Y students in various contexts by focusing on consumer shopping styles (Mandhlazi, Dhurup \& Mafini, 2014), impulsive fashion apparel consumption (Dhurup, 2014), attitude towards online shopping (Makhitha, 2014), fashion consciousness behavior (Motale, Bevan-Dye \& De Klerk, 2014) and innovation and risk-taking propensity (Koloba \& May, 2014).Against this backdrop, there remains a vast scope for research in the apparel retail setting driven by a quest to have an ongoing understanding of the variables influencing purchase decisions among shoppers in South Africa (Mafini \& Dhurup, 2015). Therefore, it can be noted that there is a paucity of empirical literature on perceived social risk, buying behavior and retail store choice decisions of Generation Y female students, thus the main objective of this study is to clear this gap in knowledge. The research study is also noteworthy in that its findings may be applicable in assisting retailers to improve and implement appropriate strategies in satisfying the needs of Generation $\mathrm{Y}$ female students.

Purpose of the Study: The study explores the association between perceived social risk and buying behavior towards retail store choice of Generation Y female students within Gauteng Province in South Africa.

\section{Literature Review}

This study reviewed literature on the concept of retail store choice, buying behavior, perceived social risk and the Generation Y consumers.

Perceived social risk: Generally, consumers have the subjective norms that they are concerned about the opinions of their family, peers and friends with respect to their own actions and subsequently their responses would be determined by people around them (Nasir, Wu, Yago \& Li, 2015). These subjective norms lead us to the concept of perceived social risk, which is generated by families' and friends' thoughts about their weak or improper choices (Bazgosha, Eizi, Nawaser \& Parhizgar, 2012). Therefore, perceived social risk confirms the dissatisfaction in the consumers by peers and household in case of a poor store choice (Ueltschy, Krampf \& Yannopoulous, 2004). Moreover, Weib (2015) emphasized that perceived social risk is a personally identified risk of suffering status loss in individual's environment. Hawkins, Mothersbaugh, \& Best (2007) mentioned that apparel, like other symbolic goods, are subjected to social risk.

Buying behavior: The behavior of the buyer with specific reference to Generation $Y$ consumers has been of interest to many retailers and researchers. This has resulted to overwhelming research exertions in pursuant of how best retailers can dispose their offerings to these elusive consumers in unpredictable markets (Mandhlazi, Dhurup \& Mafini, 2014). According to Zinyemba and Manase (2015), buying behavior denotes the purchasing behavior of individuals and households who purchase for consumption. According to Khaniwale (2015), it is not easy for consumers to decide on how best to spend their time, efforts and money. Therefore, it becomes imperative for retailers to possess extensive knowledge towards the preservation of consumers in the marketplace (Hollywood, Armstrong \& Durkin, 2007).

Retail store choice: Store choice is recognised as a mental process and much of an information processing behaviour (Sinha \& Banerjee, 2004). Rikhotso (2004), further refers to store choice as store loyalty or store patronage behaviour, In this regard, Bailey (2011) points out that the store choice might be more critical than the choice of a brand since it entails a difficult fixed decision criteria. Mason, Mayer and Ezell (1991) affirm that consumers make conscious decisions with respect to choosing retail stores they wish to patronise. The selection of a store to frequent is critical because apparel consumers will often gather information, appraise options and draw conclusions at the point of sale (Du Preez \& Visser, 2003).

Generation Y cohort: The Generation Y cohort in South Africa, comprise 38\% of the country's population (Statistics South Africa, 2014), making this cohort a significantly relevant retail segment. Williams and Page, 
(2011), further confirm that Generation $Y$ is profiled as personality-obsessed, image-driven and geared towards peer recognition as well a need for appropriateness. Furthermore, Martin and Turley (2004) argues that this cohort hold fashion in high esteem, and as such, expend the greatest part of their disposable earnings on fashionable clothing.

Conceptual framework and hypotheses: Based on the preceding discussion, the conceptual model and its related hypotheses were developed to guide the research. See Figure 1.

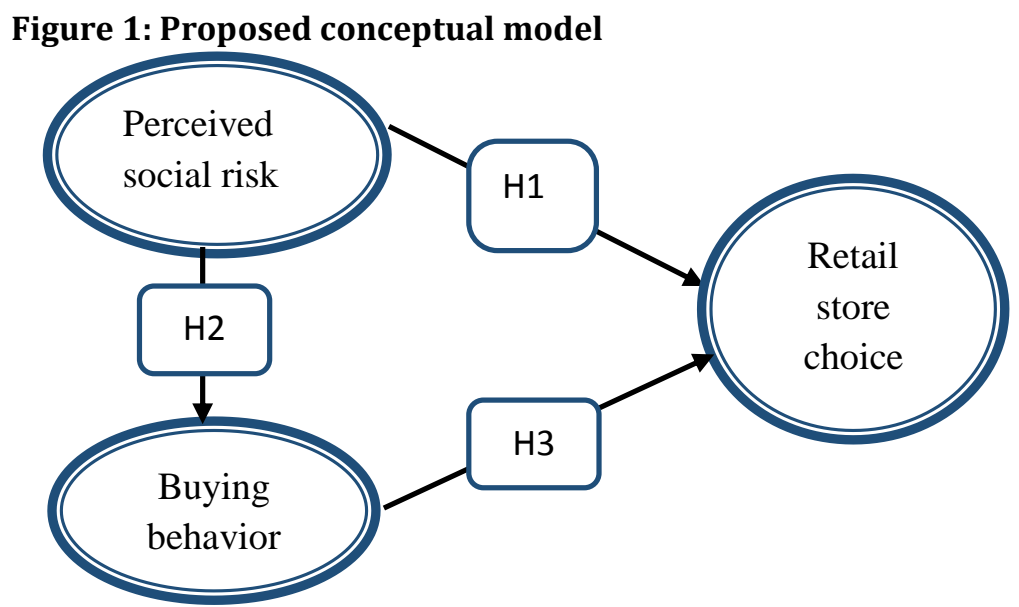

$\mathrm{H}_{1}$ : There is a positive association between perceived social and retail store choice decision of Generation $Y$ female university students.

$\mathrm{H}_{2}$ : There is a positive association between perceived social risk and buying behavior of Generation Y female university students.

$\mathrm{H}_{3}$ : There is a positive association between buying behavior and retail store choice decision of Generation $Y$ female university students

\section{Methodology and Design of Research}

This study was conducted using a quantitative research paradigm, which is deemed suitable for use to ascertain the relationships between the constructs under investigation. The survey method was adopted since it allows the use of questionnaires to collect data and control bias as the participants was requested to relate their own perception free from the researcher's intervention (Dhurup, 2014).

Sample and sampling method: The sample consisted of Generation Y female students within two universities located in southern Gauteng in South Africa using the purposively sampling procedure. This nonprobability sampling procedure was adopted in order to avoid numerous biases associated with selecting sample members from a sample frame.

Instrumentation and collection of data: The measurement tools developed for the study were informed by previous studies conducted in similar contexts and appropriate adjustments were effected in order to be suitable for the current research purpose. A self-administered structured survey questionnaire was chosen because of its accuracy since every participant was asked the same questions. Section A of the questionnaire requested the biographical profile of the participant's respondents to provide their demographic profile. Section B of the questionnaire, which assessed perceived social risk, was adopted from Zhang, Tan, Xu and Tan (2012) as well as Arslan, Gecti and Zengin (2013). Section C of the questionnaire, measured buying behavior by employing a scale adopted from Kaul (2007) and Zhang et al. (2012). In Section D, items adopted from the studies of Prashar (2013) measured retail store choice. Sections B to D items were assessed on a five-point Likert-type scale that was denoted by $1=$ strongly disagree to $5=$ strongly agree to express the degree of disagreement or agreement to various statements, while $3=$ neither disagree and neither agree. Of the 400 distributed questionnaires, 370 constituted the final analysis, which represented a response rate of 92.5 percent. 
Statistical analysis procedure: The Statistical Package for the Social Sciences (SPSS), version 23.0, was used to analyze data. The degree of association between variables under investigation was assessed using Spearman's rho. The hypothesized relationships in the research model were assessed using multiple regression analysis.

\section{Results}

Sample composition: Most participants (26.5\%) were 21 years of age, followed by (20.5\%) being 22 years of age and (17\%) being 20 years of age. For the remaining participants $(11.9 \%)$ indicated that they were 23 years of age, (11.6\%) were 19 years of age, $(8.4 \%)$ were 24 years of age, and $(4.1 \%)$ were 18 years of age. The year of study category was dominated by first year students $(35.7 \%)$, followed by third year students $(25.1 \%)$ and second year students $(21.9 \%)$. The remainder $(14.1 \%)$ was made up of fourth year and postgraduate students (3.2\%). The majority of the participants (40.3\%) spend between R600-R1000 on apparel per month, closely followed by the participants who spend between R300-R600 on apparel per month (38.4\%). Lastly, $59.2 \%$ of the participants buy apparel clothing in fashion specialty stores, 21.9 percent at boutiques and 18.9 percent at departmental stores.

Exploratory factor analysis (EFA): EFA was conducted initially on each construct in order to establish the factor structure for the constructs under review. The individual results for the study constructs are shown in Table 1.

Table 1: Results for exploratory factor analysis of the research constructs

\begin{tabular}{|c|c|c|c|c|c|}
\hline Constructs & $\begin{array}{l}\text { Bartlett's test of } \\
\text { sphericity }{ }^{1} \\
\text { Sig }\end{array}$ & $\begin{array}{l}\mathrm{KMO}^{2} \text { (sampling } \\
\text { adequacy) }\end{array}$ & $\begin{array}{c}\text { Eigen- } \\
\text { values }^{3}\end{array}$ & $\begin{array}{c}\text { \% of } \\
\text { variance }\end{array}$ & $\begin{array}{l}\text { No of } \\
\text { items }\end{array}$ \\
\hline Perceived social risk & .000 & .836 & 5.245 & 74.93 & 7 \\
\hline Buying behaviour & .000 & .857 & 5.348 & 76.40 & 7 \\
\hline Retail store choice & .000 & .860 & 5.607 & 70.09 & 8 \\
\hline
\end{tabular}

Confirmatory factor analysis (CFA): Building from the EFA, CFA was computed through the AMOS program to check the construct reliability and to ascertain whether the model fits the data. The goodness-of-fit values recommended for an acceptable model fit includes the following: chi-square/degree of freedom $(<3.0)$, incremental fit index (IFI) (>0.90), Tucker-Lewis index (TLI) $(>0.90)$, comparative fit index (CFI) $>0.90$, normed fit index (NFI) $(>0.90)$ and standard root mean square error of approximation (RMSEA) $(<0.08)(\mathrm{Hu}$ $\&$ Bentler, 1999). The total fit of the model was satisfactory. All the measures shown in Table 2, confirm a robust and acceptable model fit (Schreiber, Stage, King, Nora \& Barlow, 2006).

Table 2: Goodness-of-fit statistics

\begin{tabular}{ll}
\hline Fit indices & CFA \\
\hline Chi square/degree of freedom & 2.532 \\
IFI & 0.945 \\
TLI & 0.932 \\
CFI & 0.948 \\
NFI & 0.918 \\
RMSEA & 0.064 \\
\hline
\end{tabular}

Reliability and validity: Psychometric properties of the measurement instrument were ascertained through a reflection of its reliability and validity which are reported in Table 3.The Cronbach alpha coefficients and composite reliabilities (CR) were computed to ascertain the reliability of the measurement scales. Both 
Cronbach alpha values $(0.876 ; 0.894$ and 0.872$)$ and composite reliabilities (CR)values $(0.87 ; 0.89$ and0.88)for all the constructs under investigation respectively were greater than 0.70 , and thus regarded as adequate to prove the internal consistency of the proposed dimensions (Nunnally \& Bernstein, 1994). With regard to content validity, the measurement instrument was scrutinized by a panel of academics during the pretesting and piloting stages. The scale items in the final questionnaire sufficiently confirmed the domain of the constructs and the content validity of the questionnaire was addressed. The correlation matrix is shown in Table 3. The item-total correlations shown in Table 3ranges between 0.606 and 0.843 (i.e. all above the suggested threshold of 0.50 ), thus indicating an acceptable standards of construct validity. The results yielded supportive significant correlations between $r=0.464$ and $r=0.729$ (at p less than 0.01 ) indicating satisfactory convergent validity. In addition, the higher inter-item correlations $(>0.50)$ reveal convergence among the measured items (Anderson \& Gerbing, 1988). The results also signify an adequate inter-item convergent validity, as more than $50 \%$ percent of an individual item's variance was common with another respective construct. Discriminant validity was checked through a comparison of the average variance extracted (AVE) values with the squared correlations(SV) between the respective constructs. Since all AVE values (0.51; $0.55 a n d 0.49)$ were greater than the corresponding SV values $(0.28 ; 0.05$ and 0.08$)$, discriminant validity was confirmed (Yoshida \& James, 2010). In addition, the correlations between constructs $(<0.80)$,(See Table 3 ), provided further evidence of discriminant validity (Kline, 1998).

Correlation analysis among constructs: In order to establish the degree of the relationship between constructs under investigation, the Spearman's rho was computed. The results are reported in Table 3. Moderate to strong correlations were found between retail store choice and perceived social risk ( $\mathrm{r}=0.464$; $\mathrm{p}<0.01)$; retail store choice and buying behavior $(\mathrm{r}=0.515 ; \mathrm{p}<0.01)$ and perceived social risk and buying behavior $(\mathrm{r}=0.729$; $\mathrm{p}<0.01)$ correlations

Table 3: Correlations between constructs

\begin{tabular}{llllll}
\hline & RSC & PSR & BB & MEANS & STD DEV \\
\hline RSC & 1.000 & $.464^{* *}$ & $.515^{* *}$ & 4.16 & .631 \\
PSR & $.464^{* *}$ & 1.00 & $.729^{* *}$ & 3.79 & .903 \\
BB & $.515^{* *}$ & $.729^{* *}$ & 1.00 & 3.86 & .894 \\
\hline
\end{tabular}

${ }^{* *}$ Correlation is significant at the 0.01 level (2-tailed). $R S C=$ Retail store choice, $P S R=$ Perceived social risk, $B B=$ Buying behavior.

Regression analysis: Regression analysis was undertaken in order to check the association between the independent and dependent variables. Key assumptions were verified prior to conducting regression analysis. First, to minimize the susceptibility of regression analysis to sample sizes, the adequacy of the sample size was verified. Tabachnnik and Fiddel (2007) recommends a sample size of $\mathrm{N}>50+8 \mathrm{~m}$ (where $\mathrm{m}=$ number of independent variables) as satisfactory to compute multiple regression analysis. The sample size confirmed in the study is 301 participants, which is greater than the threshold of 66 participants in instances where two independent variables are involved. Secondly, multicollinearity was ascertained by checking the inter-correlation matrix $(<0.80)$, tolerance value $(>0.1)$ and the variance inflation factor(VIF) $(<10)$. As shown in Table 3 , there was no evidence of multicollinearity as all constructs reported intercorrelations below 0.80 . In Table 4 , both values were acceptable (highest tolerance value $=0.469$ and the highest VIF=2.132), indicating that multicollinearity did not constitute a problem in the study. Table 4indicates that none of the independent variables had VIF values of more than 10 and tolerance value of $<0.10$, affirming the absence of multicollinearity within the data set. Table 4 shows the results of regression analysis. 
Table 4: Results of regression analysis

\begin{tabular}{|c|c|c|c|c|c|}
\hline Dependent variable: & Standardized & $T$ & Sig & Collineari & tatistics \\
\hline Model 1: Independent variables & & & & Tolerance & VIF \\
\hline Perceived social risk (PSR) & 189 & 2.927 & $.004 *$ & .469 & 2.132 \\
\hline Buying behavior (BB) & .377 & 5.844 & $.000^{* *}$ & .469 & 2.132 \\
\hline $\mathrm{R}=0.531 \mathrm{R}^{2}=0.282$ Adjusted $\mathrm{R}^{2}=0.278$ & ${ }^{*}$ sig at $\mathrm{p}<0.05$ & ${ }^{* *}$ sig at $<$ & .001 & & \\
\hline $\begin{array}{l}\text { Dependent variable: Buying behavior } \\
\text { (BB) }\end{array}$ & $\begin{array}{l}\text { Standardized } \\
\text { Beta }\end{array}$ & $\mathrm{T}$ & Sig & Collinearit & atistics \\
\hline Model 2: Independent variable & & & & Tolerance & VIF \\
\hline Perceived social risk (PSR) & .705 & 19.045 & $.000^{* *}$ & 1.000 & 1.000 \\
\hline
\end{tabular}

To examine the influence of perceived social risk and buying behavior on retail store choice, regression analysis was performed (Model 1) with perceived social risk and buying behavior as independent variables and retail store choice as a dependent variable. The overall regression was significant $(\mathrm{p}<0.001 ; \mathrm{p}<0.05)$. The $\mathrm{R}^{2}$ value (0.282) indicated that approximately 28 percent of the variance in female Generation $Y$ university students pertaining to retail store choice was primarily due to their perception of their perceived social risk and buying behavior provided by an apparel store. Another regression analysis was performed (Model 2), which included perceived social risk as an independent variable and buying behavior as a dependent variable. Since previous studies have indicated a strong evidence of the influence of perceived social risk on buying behavior, Generation Y female student's perceived social risk was included as an independent variable. Overall perceived social risk explained an estimated 50 percent of buying behavior $\left(R^{2}\right.$ of 0.495$)$.

Discussion: The first hypothesis $\left(\mathrm{H}_{1}\right)$ posited that perceived social risk would exhibit a positive relationship on retail store choice among the participants. As predicted, this hypothesis was supported ( $\beta=0.189$, t-value $=2.2927, \mathrm{p}<0.000$ ). This result was also substantiated by a significant correlation of $\mathrm{r}=0.464$. In addition, the perceived social risk construct scored a summated mean of 3.4834 out of 5 . This result suggests that female Generation Y consumers attach significant social value to apparel retail store choice. This result is further supported by previous studies of Liang, Lu and Tu (2006), which indicated a significant influence of perceived risk on customer's decision-making process. Horvat and Dosen (2013) also confirmed that perceived risk bears a substantial influence on consumer attitudes.

The second hypothesis $\left(\mathrm{H}_{2}\right)$ posited that perceived social risk would exhibit a positive relationship on buying behaviour amongthe participants. This hypothesis was reinforced by a significant effect $(\beta=0.705, \mathrm{t}$-value $=$ $19.045, \mathrm{p}<0.01$ ). This result was also supported by the existence of a significant positive correlation of $\mathrm{r}=0.729$. In addition, the perceived social risk construct scored a summated mean of 3.4834 out of 5 implying that the majority of the respondents perceived social risk as critical. This result is supported by the studies conducted by Arslan, Gecti and Zengin (2013) that revealed that perceived social risk is connected largely with buying behavior. Xue (2015), as well confirmed that consumer's buying behavior is influenced by perceived risks.

The third hypothesis $\left(\mathrm{H}_{3}\right)$ predicted that buying behavior would exhibit a positive relationship on retail store choice among the participants. This hypothesis was confirmed $(\beta=0.377, \mathrm{t}$-value $=5.844, \mathrm{p}<0.000)$. This result was also corroborated by a significant positive correlation $r=0.515$. In line with this hypothesis, the buying behaviour construct recorded a summated mean of 3.6166 out of 5 . This finding is pertinent in the sense that Sinha, Banerjee and Uniyal (2002) studies identified store choice to rely on consumers' behavior and past purchase experience. Furthermore, Goodman, Lockshin and Renau (2010) confirmed that buying behavior generally is directed by consumer perception and largely by the store, which fulfils the needs of the consumer at that particular occasion of consumption. Hasan (2015) conclusively asserts that formation of certain judgments about the store influences how a buyer behaves.

Limitations and Implications for Further Research: The researchers acknowledge limitations to the study which offer opportunities for further research. Firstly, the non-probability convenient sampling technique employed in the study suffers from the limitations inherent in non-probability sampling techniques and also 
restricts the generalisability of the research findings. Future studies should consider using probability sampling techniques to enhance the generalizability of the results. In addition, the study was confined to the female Generation Y cohort. Against this backdrop, further research should incorporate other generational cohorts such as Generation X so that more critical evidence may be collected to segments markets and to develop suitable retail strategies.Another limitation concerns the use of a single method of data collection, as the study employed a quantitative research paradigm. Complementing quantitative with qualitative research will be advantageous as this will provide richer data and support the findings of the study. Further research may consider using triangulation methodology that would incorporate both qualitative and quantitative research designs.

\section{Conclusion}

In today's competitive retailing industry, fashion retailers who currently target, or who are planning to target, the Generation Y female student cohort need to familiarise themselves with this market. An appreciation of what motivates this generation to choose apparel retail store and the identification of in-store and out-store events inspires customers to stay loyal. Therefore, it is imperative for apparel retailers to inculcate an appreciation of how perceived social risk and buying behaviour influences store selection to apparel consumers. Future research can be conducted to overcome the mentioned limitations of this study.

Recommendations: Apparel retailers have to alter their current marketing strategies or adapt them to respond to continuous changes in needs. In addition, apparel retailers can reduce perceived social risk through provision of sufficient information for a consumer to feel comfortable in making decisions, thus reducing perceived social risk. Furthermore, retail store managers must provide a good service to consumers in order to build positive shopping experiences for apparel products purchasing. Familiar brands and guarantees of satisfaction can assist to diminish perceived social risks. In addition, point of purchase advertisements, product displays and well-informed sales personnel can supply customers with the information they need.It is imperative for apparel retailers within southern Gauteng to have a clear understanding of the buying behaviour of consumers, more specifically the needs, wants and preferences of the Generation Y female cohort so that they can respond accordingly. Apparel retailers can make use of the biographical information as a basis for segmenting this market. Information such as age, ethnical group and year of study can help them in identifying exactly who their customers are, which advertising media will appeal to them and finally, how long will they study at their respective institutions of higher learning. It is further recommended that the validated measuring instrument in the study be employed as a diagnostic methodology to uncover broad areas of perceived social risk, buying behavior and retail store choice decisions among Generation Y female university students.

\section{References}

Amin, S. \& Mahasan, S.S. (2014). Relationship Between Consumers Perceived Risks and Consumer Trust: A Study of Sainbury Store. Middle East Journal of Scientific Research, 19(5), 647-655.

Anderson, J. \& Gerbing, D. (1988). Structural Equation Modeling in Practice: A Review and Recommended Two Step Approach. Psychological Bulletin, 103, 411-423.

Arslan, Y., Gecti, F. \&Zengin, H. (2013). Examining perceived risk and its influence on attitudes: A study on private label consumers in Turkey. Journal of Asian Social Science, 9(4), 158-156.

Bailey, J.F. (2011). Customer buying behaviour at selected petroleum shops in Cape Town, Unpublished Master's Degree Dissertation. Cape Town. Cape Peninsula University of Technology.

Bazgosha, G., Eizi, N., Nawaser, K. \& Parhizgar, M.M. (2012). Technology of e-banking: perspective of costumers' perceived risk and uncertainty. Indian Journal of Science and Technology, 5(2), 22002208.

Bevan-Dye, A.L., Garnett, A. \& De Klerk, N. (2012). Materialism, status consumption and consumer ethnocentrism amongst black Generation Y students in South Africa. African Journal of Business Management, 6(16), 5578-5586.

Carpenter, J.M. \& Brosdahl, D. J. (2011). Exploring retail format choice among US males. International Journal of Retail \& Distribution Management, 39(12), 886-898. 
Cooper, B. (2010). Establishing the store attributes that black consumers consider when buying casual wear, Unpublished Master's Degree Dissertation. Potchefstroom. North West University.

De Klerk, M.H. \& Lubbe, S. (2008). Female consumer's evaluation of apparel quality: Exploring the importance of aesthetics. Journal of Fashion Marketing \&Management, 12(1), 36-50.

Dhurup, M. (2014). Impulsive fashion apparel consumption: the role of hedonism, fashion involvement and emotional gratification in fashion apparel impulsive buying behavior in a developing country, Mediterranean Journal of Social Sciences, 5(8), 168-177.

Diejomaoh, G.G. (2013). Buying Behavior of Consumer on Food and Nonfood from Retail Market (A Case on Nigeria Consumer). Doctoral dissertation. Universitas Roskildensis, Roskilde.

Du Plessis, P.J. \& Rousseau, G.G. (2003). Buyer behavior: a multi-cultural approach (3rd Ed). Cape Town. Oxford University Press.

Du Preez, R. \& Visser, E. M. (2003). Apparel shopping behavior- Part 2: Conceptual theoretical model, market segments, profiles and implications. SA journal of industrial psychology, 29(3), 15-20.

Faarup, P.K. (2010). The Marketing Framework: International marketing and sales. London: Academic. Fairchild Books

Floor, K. (2006). Branding a store: How to build successful retail brands in a changing marketplace. London, Kogan Page Publishers.

Goodman, S., Lockshin, L. \& Remau, H. (2010). Where to shop? The influence of store choice characteristics on retail market segmentation. Refereed paper - 5th International Academy of Wine Business Research Conference, 8-10 Feb. 2010 Auckland (NZ).

Hasan, A. (2015). Key Drivers Influencing Shopping Behavior in Retail Stores. Journal of Inspiration Economy, 2(1), 7-33.

Hawkins, D.I., Mothersbaugh, D.L. \& Best, R.J. (2007). Consumer behavior: building marketing strategy (10th Ed). New York. McGraw-Hill.

Hollywood, L.E., Armstrong, G. A. \& Durkin, M.G. (2007). Using behavioral and motivational thinking in food segmentation. International Journal of Retail \& Distribution Management, 35(9), 691-702.

Horvat, S. \& Došen, D.O. (2013). Perceived Risk Influence on the Consumer Attitude to Private Labels in the Product's Life Cycle Growth Stage. Economic and Business Review, 15(4), 267-91.

Hu, L. \& Bentler, P.M. (1999). Cutoff criteria for fit indexes in covariance structure analysis: Conventional criteria versus alternatives. Structural Equation Modeling, 6(1), 1-55.

Jayasankaraprasad, C. (2010). Effect of situational factors on store format choice behavior in food and grocery retailing in India- multiple discriminant analysis. IBSU Scientific Journal, 4(2), 5-33.

Karpova, E., Hodges N. N. \& Tullar, W. (2007). Making sense of the market. An exploration of apparel consumption practices of the Russian consumer. Journal of Fashion Marketing \& Management, 11(1), 106-121.

Kaul, S. (2007). Hedonism and culture: impact on shopping behavior a research agenda, The Journal for Decision Makers, 32(3), 81-89.

Khaniwale, M. (2015). Consumer Buying Behavior. International Journal of Innovation and Scientific Research, $14(2), 278-286$.

Kline, R.B. (1998). Principles and practice of structural equation modeling. New York: The Guildford Press.

Koloba, H. A. \& May, C. (2014). Innovation and risk-taking propensity of Generation Y students in South Africa. Mediterranean Journal of Social Sciences, 5(21), 19-26.

Leszczyc, P., Peter, T.L., Sinha, A. \& Timmermans, H.J.P. (2000). Customer store choice dynamics: An analysis of the competitive market structure for grocery stores. Journal of Retailing, 76(3), 323-346.

Liang, H., Lu, D. \& Tu, C. (2006). The perceived risk and the consumer decision making process: A study on credit cards holders. Masters Dissertation. Kristianstad, Sweden: Kristianstad University.

Mafini, C. \& Dhurup, M. (2015). Drivers of Customer Loyalty in South African Retail Stores. Journal of Applied Business Research, 31(4), 1295-1310.

Makhitha, K.M. (2014). Factors influencing Generation Y students' attitude towards online shopping, Mediterranean Journal of Social Sciences, 5(21), 39-50.

Mandhlazi, L., Dhurup, M. \& Mafini, C. (2014). Generation Y consumer shopping styles: evidence from South Africa. Mediterranean Journal of Social Sciences, 4(14), 153-164.

Martin, C. A. \& Turley, L.W. (2004). Malls and consumption motivation: an exploratory examination of older Generation Y consumers. International Journal of Retail \& Distribution Management, 32(9), 464-474.

Mason, J.B., Mayer, M.L. \& Ezell, H. F. (1991). Retailing. 4th ed. Boston: Irvin 
Motale, M.D.B., Bevan-Dye, A. L. \& De Klerk, N. (2014). African Generation Y male students' fashion consciousness behavior. Mediterranean Journal of Social Sciences, 5(21), 121-128.

Mowen, J.C. (1995). Consumer behavior, 4th ed. Englewood Cliffs, N.J: Prentice-Hall

Muzondo, N. \& Mutandwa, E. (2011). The Seven Ps of Marketing and Choice of Main Grocery Store in a hyper inflationary Economy. Contemporary Marketing Review, 1(9), 01 - 18.

Nasir, M.A. Wu, J., Yago, M. \& LI, H. (2015). Influence of Psychographics and Risk Perception on Internet Banking Adoption: Current State of Affairs in Britain. International Journal of Economics and Financial Issues, 5(2), 461-468

Nunnally, J.C. \& Bernstein, I.H. (1994). Psychometric Theory. (3rd Ed). New York. McGraw-Hill.

Peter, J.P. \& Olson, J.C. (2005). Consumer behavior and marketing strategy. Saddle River, New Jersey: Prentice Hall.

Prasad, C.J. (2012). Effect of shopper attributes on retail format choice behavior for food and grocery retailing in India. International Journal of Retail \& Distribution Management, 39(1), 68-86.

Prashar, A. (2013). Driver of store choice in an evolving market: An empirical study. International Journal of Advancements in Research and Technology, 2(8), 195-202.

Rikhotso, T.V. (2004). Personal Characteristics, Perception of Store Image Attributes and Store Choice of Black Female Clothing Shoppers. Magister dissertation in Consumer Sciences (Clothing). Potchefstroom. North West University.

Schiffman, L. G. \& Kanuk, L.L. (2007). Consumer behavior. (9th Ed). Upper Saddle River. Prentice Hall.

Schreiber, J.B., Nora, A., Stage, F.K., Barlow, E.A. \& King, J. (2010). Reporting structural equation modeling and confirmatory factor analysis results: a review. The Journal of Educational Research, 99(6), 323-338.

Sinha, P.K., Banerjee, A. \& Uniyal, D. P. (2002). Deciding where to buy: Store choice behavior of Indian shoppers. Vikalpa, 27(2), 13-28.

Sinha, P. K. \& Banerjee, A. (2004). Store choice behaviour in an evolving market. International Journal of Retail \& Distribution Management, 32(10), 482-494.

Statistics South Africa. (2014). Mid-year population estimates: Statistical release p302. http://beta2.statssa.gov.za/publications/P0302/P03022014.pdf Date of access: 10 Apr. 2015.

Tabachnick, B.G. \& Fidell, L. S. (2007). Using Multivariate Statistics (5th Ed.). New York. Allyn and Bacon.

Ueltschy L.C., Krampf, R.F. \& Yannopoulos, P. (2004). A Cross National Study of Perceived Consumer Risk towards Online (internet) Purchasing. The multinational Business Review, 12(2), 59-82.

Weib, S. (2015). Determinants of Private Label Attitude: Predicting Consumers' Brand Preferences Using Psychographics. Austria. Springer.

Williams, K.C. \& Page, R. A. (2011). Marketing to the generations. Journal of Behavioral Studies in Business, 3, $1-17$.

Xue, D.F. (2015). Analyze the relation between perceived risk and customer involvement: Based on the Bank financial products. International Journal of Economics, Commerce and Management, 3(2), 1-7.

Yoshida, M. \& James, J.D. (2010). Customer satisfaction with game and service experiences: Antecedents and Consequences. Journal of Sport Management, 24, 338-361.

Zhang, L., Tan, W., Xu, Y. \& Tan, G. (2012). Dimensions of consumers' perceived risk and their influences on online consumers' purchasing behavior. Journal of Communications in Information Science and Engineering, 2(7), 8-14.

Zinyemba, A.Z. \& Manase, I. (2015). Effects of advertising on consumer behavior in low-density houses: the case of Marlborough, Zimbabwe. International Journal of Business, Economics and management, 2(4), 91-99.

Zulqarnain, H., Zafar, A.U. \& Shahzad, M. (2015). Factors that affect the choice of Consumers in selecting Retail Store, for Grocery Shopping. International Journal of Multidisciplinary and Current Research, 3(1), 1167-1172. 